\title{
Cryptosporidium spp. infection in mares and foals of the northwest region of São Paulo State, Brazil
}

\author{
Infecção por Cryptosporidium spp. em éguas e potros da região noroeste do Estado de São Paulo, Brasil \\ Sandra Valéria Inácio ${ }^{1 *}$; Roberta Lomonte Lemos de Brito²; Anaiza Simão Zucatto1; Willian Marinho Dourado Coelho²; \\ Monally Conceiçẫo Costa de Aquino ${ }^{1}$; André de Abreu Rangel Aguirre'; Silvia Helena Venturoli Perri' ${ }^{1}$; \\ Marcelo Vasconcelos Meireles ${ }^{1}$; Katia Denise Saraiva Bresciani ${ }^{1}$
}

${ }^{1}$ Faculdade de Medicina Veterinária, Universidade Estadual Paulista - UNESP, Araçatuba, SP, Brasil

${ }^{2}$ Faculdade de Ciências Agrárias e Veterinárias, Universidade Estadual Paulista - UNESP, Jaboticabal, SP, Brasil

Received February 1, 2012

Accepted June 1, 2012

\begin{abstract}
The present study aimed to analyze the occurrence of infection by Cryptosporidium spp. in mares and their respective foals. This study was carried out in 11 farms located in the municipalities of Araçatuba, Birigui, Guararapes and Santo Antônio do Aracangua, in the northwest region of the State of Sao Paulo, from November 2010 to March 2011. A total of 98 mares and 98 foals of several breeds were analyzed; among foals, 59 were males and 39 females, aged from three to 330 days. Feces were collected directly from the rectal ampulla, purified and processed according to modified Kinyoun stain. Occurrence of Cryptosporidium spp. was 21.4\% (21/98) for foals and 18.4\% (18/98) for mares. Occurrence of Cryptosporidium spp. had significant association with breeds and age of animals. Results obtained led to the conclusion that foals older than two months and Mangalarga animals are less susceptible to the occurrence of Cryptosporidium spp.
\end{abstract}

Keywords: Cryptosporidium, frequency, mares, foals.

\section{Resumo}

O presente estudo teve como objetivo analisar a ocorrência da infecçáo por Cryptosporidium spp. em éguas e seus respectivos potros. Este estudo foi realizado em 11 fazendas localizadas nos municípios de Araçatuba, Birigui, Guararapes e Santo Antônio do Aracangua, na região Noroeste do Estado de São Paulo, de novembro de 2010 a março de 2011. Um total de 98 éguas e 98 potros de diversas raças foram analisados, sendo que, entre os filhotes, 59 eram machos e 39 fêmeas, cujas idades variavam de três até 330 dias. Fezes foram colhidas diretamente da ampola retal, purificadas e processadas pela técnica de Kinyoun modificada. A ocorrência de Cryptosporidium spp. observada foi de 21,4\% (21/98) para potros e 18,4\% (18/98) para éguas. A ocorrência de Cryptosporidium spp. teve uma associaçáo significativa com a raça e a idade dos animais. A partir dos resultados obtidos, conclui-se neste estudo que potros com idade superior a dois meses e animais da raça Mangalarga foram menos susceptíveis à ocorrência de Cryptosporidium spp.

Palavra-chave: Cryptosporidium, frequência, éguas, potros.

\section{Introduction}

Birds, amphibians, reptiles and mammals, including humans, can be different host species for Cryptosporidium spp. (FAYER, 2010; SMITH; NICHOLS, 2010; PLUTZER; KARANIS, 2009).

The protozoa Cryptosporidium spp. is included in the Neglected Diseases Initiative of the World Health Organization (WHO) due to their close relationship with deficient sanitation and low income of the population; thus, they are considered responsible for child malnutrition and death (THOMPSON et al., 2008).

\footnotetext{
${ }^{*}$ Corresponding author: Sandra Valéria Inácio

Faculdade de Medicina Veterinária, Universidade Estadual Paulista - UNESP, Rua Clóvis Pestana, 793, Dona Amélia, CEP 16050-680, Araçatuba, SP, Brasil e-mail: sandra_byol@yahoo.com.br
}

Fecal oocysts of Cryptosporidium spp. released by equine may represent a source of human infection and are resistant to the environmental conditions (PLUTZER; KARANIS, 2009).

Evaluation of the occurrence of Cryptosporidium spp. in horses has drawn the attention of research worldwide (BURTON et al., 2010; COLE et al., 1998; JOHNSON et al., 1997; MAJEWSKA et al., 2004; MARQUES, 2010; SOUZA et al., 2009; VERONESI et al., 2009). Positive fecal samples for Cryptosporidium parvum oocysts were significantly greater for foals under six months of age and thoroughbreds compared to other breeds, in Texas (COLE et al., 1998). 
Few studies have been carried out in Brazil (MARQUES, 2010; SOUZA et al., 2009). Therefore, data on the occurrence of Cryptosporidium spp. in equine species are still scarce.

The protozoan Cryptosporidium spp. has been associated with the presence of diarrhea in immunocompetent and immunodeficient animals (BJORNEBY et al., 1991; COLEMAN et al., 1989; GIBSON et al., 1983; GRINBERG et al., 2003; MAIR et al., 1990). Nevertheless, some clinical and epidemiological aspects of this infection are still not clear (VERONESI et al., 2009).

Meireles (2010) discussed this situation in researches carried out in Brazil on domestic and wild animals infected with Cryptosporidium spp. demonstrating the increasing amount of works on this theme.

The present research aimed to analyze the occurrence of infection by Cryptosporidium spp. in mares and their respective foals in municipalities of the northwest region of the State of Sao Paulo and to correlate the positivity for this parasite with the variables breed, sex, age, degree of fecal hydration, and water source.

\section{Materials and Methods}

This study was approved by the Ethics Committee for Animal Use of the Dentistry School of UNESP, Araçatuba Campus; protocol number 2009-002165.

This study was carried out in 11 farms located in the municipalities of Araçatuba, Birigui, Guararapes and Santo Antônio do Aracangua, in the northwest region of the State of Sao Paulo, from November 2010 to March 2011. A total of 98 mares and their respective foals were investigated. Breeds were as follows: $50.51 \%$ (50/98) Quarter Horse, 42.42\% (42/98) Mangalarga Marchador, 5.05\% (5/98) Paint Horse, and 1.01\% (1/98) Crioula; among foals, 59 were males and 39 females, aged between three and 330 days. Foals were allocated, according to age, in two groups: $\leq 60$ days and $>60$ days.

An epidemiological questionnaire was applied to the owners, addressing questions related to age, sex, breed and types of water source for the equines involved in the research.

Fecal samples were collected directly from the rectal ampulla of animals and stored under refrigeration; subsequently, fecal smears were prepared. To standardize the determination of the degree of fecal hydration, the following classification was adopted: solid, semi-solid, pasty and liquid. The following established criterion was used regarding the color: green, mossy green, brown, yellowish green and yellow. Information about fecal conditions was introduced in the data bank to correlate the physical status of feces to the occurrence of the parasite, also including the variables: age, sex, breed, and types of water source (river, pond, millpond, draw-well, water tank) used by the animals involved in this study.

Fecal smears were prepared by centrifugation-sedimentation technique in water and ether (MELONI; THOMPSON, 1996) used in the routine laboratory and, subsequently, stained according to the modified Kinyoun technique (LENNETTE et al., 1985) for observation of Cryptosporidium spp. oocysts.

A light optical microscope, $40 \times$ and $100 \times$ magnification, was employed for observation. Infection by Cryptosporidium spp. was classified into positive or negative, based on the presence or absence of oocysts in one sample from each animal.
Variables were analyzed according to the Chi-square test $\left(\chi^{2}\right)$ or Fisher's exact test and Mann-Whitney test (ZAR, 1999), employing SAS software (SAS, 2008), at 5\% significance level.

\section{Results and Discussion}

Occurrence of Cryptosporidium spp. was detected, using Kinyoun stain, in $21.4 \%$ (21/98) of the foals and $18.4 \%$ (18/98) of the mares analyzed. Foals presented higher occurrence of Cryptosporidium spp. compared to adult mares, which corroborates the findings by Burton et al. (2010).

There was positivity of $12.2 \%$ (12/98) of samples for both foals and their respective mothers; however, there was no significant association. Mature horses are not considered important sources of infection for foals (COLE et al., 1998) and the infection of foals was not associated with that of their mothers (MAJEWSKA et al., 2004).

Compared to the occurrence of infection by Cryptosporidium spp. in the equines detected herein, studies have described lower frequencies: $0 \%(0 / 91)$ by Johnson et al. (1997) in California, USA and $0.75 \%$ (3/396) by Souza et al. (2009) in Rio de Janeiro, Brazil. However, a higher frequency of $27.8 \%$ (25/90) of Cryptosporidium spp. infection was obtained using Ziehl-Neelsen staining technique by Marques (2010) in Porto Alegre, Brazil. Thus, asymptomatic adult horses can be considered sources of environmental contamination due to the fecal content they produce (MARQUES, 2010).

Foals younger than two months were more susceptible to Cryptosporidium spp. infection ( $\mathrm{p}=0.0069)$, with $37,5 \%(12 / 32)$ occurrence, while the group older than 60 days showed 13,6\% $(9 / 66)$ of positive samples (Table 1$)$. Two positive samples from 60 and 90-day-old foals were liquid feces and one positive mother presented feces of pasty consistency.

Cole et al. (1998) reported diarrhea related to the presence of the above-mentioned protozoan, and Grinberg et al. (2003) seemed to have evidenced this clinical sign in immunocompetent foals. In the present study, the consistency $(\mathrm{p}=0.2119$ and $\mathrm{p}=0.2403)$ and color $(\mathrm{p}=0.6842$ and $\mathrm{p}=0.5023)$ of feces were not associated with the occurrence of this disease in foals and mares, respectively, which agrees with the reports by Veronesi et al. (2009) and Burton et al. (2010).

As regards the breed, there was a significant association ( $\mathrm{p}<0.0001$ ) between the occurrence of Cryptosporidium spp. and the breed of foals, with 30.0\% (15/50) positivity for Quarter Horse, 2.4\% (1/42) for Mangalarga Marchador, 80.0\% (4/5) for Paint Horse, and $100 \%$ (1/1) for Crioula (Table 1). However, Cole et al. (1998) reported non-significant association for Thoroughbred horses.

In this study, there was no significant association between the protozoan occurrence and the sex of foals $(\mathrm{p}=0.1838)$ (Table 1$)$; the same was found for the sources of water drunk by the animals in the farm $(\mathrm{p}=0.4877)$.

Souza et al. (2009) noted higher proportion of males naturally infected by Cryptosporidium spp. and concluded that the disease in equines, with different management types, is probably related to the immunological state and sanitary conditions found in the place where they live, since they were already considered sources of environmental infection (VERONESI et al., 2009). Concerning 
Table 1. Occurrence of infection by Cryptosporidium spp. by modified Kinyoun stain according to the variables breed, sex and age from 98 foals in the northwest region of the State of Sao Paulo, 2012.

\begin{tabular}{|c|c|c|c|c|c|}
\hline \multirow{2}{*}{ Variable } & \multirow{2}{*}{ Category } & \multirow{2}{*}{$\mathbf{n}$} & \multicolumn{2}{|c|}{ Occurrence } & \multirow{2}{*}{ P-value } \\
\hline & & & Positive & $\%$ & \\
\hline \multirow{4}{*}{ Breed } & Quarter Horse & 50 & 15 & 30,0 & \multirow{4}{*}{$<0.0001^{(1)}$} \\
\hline & Mangalarga Marchador & 42 & 1 & 2,4 & \\
\hline & Paint Horse & 5 & 4 & 80,0 & \\
\hline & Crioula & 1 & 1 & 100,0 & \\
\hline \multirow{3}{*}{ Sex } & Male & 59 & 10 & 16,9 & \multirow{3}{*}{$0.1838^{(2)}$} \\
\hline & Female & 39 & 11 & 28,2 & \\
\hline & Total & 98 & 21 & 21,2 & \\
\hline \multirow{2}{*}{ Age (days) } & $\leq 60$ & 32 & 12 & 37,5 & \multirow{2}{*}{$0.0069^{(2)}$} \\
\hline & $>60$ & 66 & 9 & 13,6 & \\
\hline
\end{tabular}

${ }^{(1)}$ Fisher's exact test; ${ }^{(2)}$ Chi-square.

this aspect, it must be highlighted that, in previous epidemiological studies, Cryptosporidium spp. infection was concentrated on one farm or site, and this may be due to the characteristics of the management adopted in the farm (VERONESI et al., 2009; BURTON et al., 2010).

\section{Conclusion}

The results obtained led to the conclusion that foals older than two months and the breed Mangalarga were less susceptible to the occurrence of Cryptosporidium spp.

\section{References}

Bjorneby JM, Leach DR, Perryman LE. Persistent Cryptosporidiosis in Horses with Severe Combined Immunodeficiency. Infect Immun 1991; 59(10): 3823-3826. PMid:1894380 PMCid:258958.

Burton AJ, Nydam DV, Dearen TK, Mitchell K, Bowman DD, Xiao L. The prevalence of Cryptosporidium, and identification of the Cryptosporidium horse genotype in foals in New York State. Vet Parasitol 2010; 174(1-2): 139-144. PMid:20932647. http://dx.doi. org/10.1016/j.vetpar.2010.08.019

Cole DJ, Cohen ND, Snowden K, Smith R. Prevalence of and risk factors for fecal shedding of Cryptosporidium parvum oocysts in horses. J Am Vet Med Assoc 1998; 213(9): 1296-1302. PMid:9810386.

Coleman SU, Klei TR, French DD, Chapman MR, Corstvet RE. Prevalence of Cryptosporidium spp. in equids in Louisiana. Am J Vet Res 1989; 50(4): 575-577. PMid:2712425.

Fayer R. Taxonomy and species delimitation in Cryptosporidium. Exp Parasitol 2010; 124(1): 90-97. PMid:19303009. http://dx.doi. org/10.1016/j.exppara.2009.03.005

Gibson JA, Hill MWM, Huber MJ. Cryptosporidiosis in Arabian foals with severe combined immunodeficiency. Aust Vet J 1983; 60(12): 378-379. PMid:6667218. http://dx.doi.org/10.1111/j.1751-0813.1983. tb02853.x

Grinberg A, Oliver L, Learmonth JJ, Leyland M, Roe W, Pomroy WE. Identification of Cryptosporidium parvum "cattle" genotype from a severe outbreak of neonatal foal diarrhoea. Vet Rec 2003; 153(20): 628-631. PMid:14653344. http://dx.doi.org/10.1136/vr.153.20.628
Johnson E, Atwill ER, Filkins ME, Kalush J. The prevalence of shedding of Cryptosporidium and Giardia spp. based on a single fecal sample collection from each of 91 horses used for backcountry recreation. $J$ Vet Diagn Invest 1997; 9(1): 56-60. PMid:9087926. http://dx.doi. org/10.1177/104063879700900110

Lennette EH, Balows A, Hausler Junior WJ, Shadomy HJ. Manual of clinical microbiology. 4th ed. Washington: American Society of Microbiology; 1985. p. 1149.

Mair TS, Taylor FG, Harbour DA, Pearson GR. Concurrent Cryptosporidium and Coronavirus infections in an Arabian foal with combined immunodeficiency syndrome. Vet Rec 1990; 126(6): 127-130. PMid:2156372.

Majewska AC, Solarczyk P, Tamang PSL, Graczyk TK. Equine Cryptosporidium parvum infections in western Poland. Parasitol Res 2004; 93(4): 274-278. PMid:15156396. http://dx.doi.org/10.1007/ s00436-004-1111-y

Marques SMT. Cryptosporidiosis in Horses of Urban Areas of Porto Alegre, Rio Grande do Sul, Southern Brazil. J Equine Vet Sci 2010; 30(7): 356-358. http://dx.doi.org/10.1016/j.jevs.2010.05.006

Meloni BP, Thompson RCA. Simplified methods for obtaining purified oocysts from mice and for growing Cryptosporidium parvum in vitro. J Parasitol 1996; 82(5): 757-762. PMid:8885885. http://dx.doi. org/10.2307/3283888

Meireles MV. Cryptosporidium infection in Brazil: implications for veterinary medicine and public health. Rev Bras Parasitol Vet 2010; 19(4): 197-204. PMid:21184694. http://dx.doi.org/10.1590/ S1984-29612010000400002

Plutzer J, Karanis P. Genetic polymorphism in Cryptosporidium species: an update. Vet Parasitol 2009; 165(3-4): 187-199. PMid:19660869. http://dx.doi.org/10.1016/j.vetpar.2009.07.003

Smith HV, Nichols RAB. Cryptosporidium: detection in water and food. Exp Parasitol 2010; 124(1): 61-79. PMid:19501088. http://dx.doi. org/10.1016/j.exppara.2009.05.014

Souza PNB, Bomfim TCB, Huber F, Abboud LCS, Gomes RS. Natural infection by Cryptosporidium sp., Giardia sp. and Eimeria leuckarti in three groups of equines with different handlings in Rio de Janeiro, Brazil. Vet Parasitol 2009; 160(3-4): 327-333. PMid:19117684. http://dx.doi. org/10.1016/j.vetpar.2008.10.103

Statistical Analisys System Institute - SAS. The Statistical analysis system. release 9.2. Cary: SAS Institute Inc.; 2008. 
Thompson RCA, Palmer, CS, O'Handley R. The public health and clinical significance of Giardia and Cryptosporidium in domestic animals. Vet J 2008; 177 (1): 18-25. PMid:18032076. http://dx.doi. org/10.1016/j.tvjl.2007.09.022

Veronesi F, Passamonti F, Cacciò S, Diaferia M, Fioretti DP. Epidemiological Survey on Equine Cryptosporidium and Giardia
Infections in Italy and Molecular Characterization of Isolates. Zoonoses Public Health 2009; 57(7-8): 510-517. PMid:19912609. http://dx.doi. org/10.1111/j.1863-2378.2009.01261.x

Zar JH. Biostatistical analysis. Upper Saddle River: Prentice Hall; 1999. p. 930. 